\title{
ESTIMATION OF RISK FACTORS OF THE WORK ENVIRONMENT AND ANALYSIS OF EMPLOYEES' SELF ESTIMATION IN THE WOOD PROCESSING INDUSTRY
}

\author{
Ivars Vanadziņš, Maija Eglīte, Mārīte Ārija Baḳe, Dagmāra Sprūdža, Žanna Martinsone, \\ Inese Mārtinssone, N̦ina Rusakova, Anita Piḳe, and Pāvels Sudmalis
}

Institute of Occupational Safety and Environmental Health, Rīga Stradiṇš University, Dzirciema iela 16, Rīga, LV-1007, LATVIA
E-mail: ivars.vanadzins@ @rsu.Iv

Communicated by Andrejs Skaǵers

The aims of our study were to determine risk factors of the work environment in the wood processing industry in Latvia during 1998-2006, to conduct a survey and self- evaluation of health of the employees and to elaborate a set of preventive measures for improvement of the work environment. The work conditions in wood processing companies in Latvia over the study period were poor; of a total of 940 evaluated workplaces/processes in more than one half of cases $(n=$ 483), the risk factors of the working environment exceeded the occupational exposure limits. Measurements made in wood processing and furniture manufacturing most frequently limiting values or recommended values of the occupational exposure were exceeded for noise, indoor air, lighting, welding spray, whole-body vibration, wood dust and other risk factors. Self-evaluation of health by employees indicates that the main health problems were pain in the back and joints, poor hearing, eye irritation, skin irritation and inflammation, chronic coughing, rhinitis, recurring windpipe inflammations, and frequent headaches. Self-evaluation of employees indicated poor diagnostics of occupational diseases and work related diseases as for $82 \%$ of the respondents with health complaints they were not confirmed with medical diagnosis.

Key words: wood processing industry, risk factors of work environment, noise, vibration, wooden dust, chemicals, microclimatic conditions, ergonomical factors.

\section{INTRODUCTION}

In Latvia wooden and cork product industries are among the leaders in the economy, and are continuously being modernised and improved. Approximately $14 \%$ of the inhabitants of Latvia who are employed work in the wood processing industry. There are more than 3,000 companies registered in the Register of Companies, who have indicated woodprocessing, manufacture of wooden products, production of veneer and furniture makers as part of their operations.

Several different activities of wood processing are included in the wood-processing industry. It is a difficult industry from the perspective of labour safety and occupational health, because the employed are subjected to very varied risk factors of the work environment. Wood processing in its structure is not homogeneous, because it includes various production processes, such as sawing timber, milling, turning, planed timber processing, grinding (polishing), pressing, boring, gluing, painting, lacquering, and drying. Therefore, the industry can be characterised with nearly all risk factors of the work environment that influence or that can influence the health condition of the employed.

Studies have shown that the majority of the employees of the wood processing industry are simultaneously subjected to the effects of several risk factors: dust, noise, vibrations, chemical substances, unbeneficial microclimatic conditions, biological factors, and extensive physical load (Innos et al., 2000; Mandryk et al., 2000; Mikkelson et al., 2002; Priha et al., 2004).

Wood dust is a complex mixture. It can contain pure substance of the processed material or it can be mixed with dust of abrasive materials, chemical substances, finishing materials, or anti-septic substances, and it contains micro-organisms (Kauppinen et al, 1997; Staša and Roja, 2001; Kraus et al., 2004).

Besides wood dust, people employed in wood processing often are subjected to chemical substances, which are secreted from the wood or which are used in wood processing, and also to biological factors (Douves et al., 2000; Dutkiewicz et al., 2001; Schlunssen et al., 2001).

Wood dust has irritant, fibrogenic, allergic, toxic, and cancerogenic influence on the body, depending on the physicalchemical properties of dust (structure, shape, amount, solidity, liquidity, explosiveness), concentration in the air of the work environment and duration of impact. Diseases caused by wood dust most frequently effect respiratory organs, eyes, and skin (Demers et al. 1997; Donham and Thorne, 1994; Kauppinenet et al., 2006). 
The above-mentioned risk factors affecting wood processing workers have been much studied world wide. Other risk factors have not been considered as much. The available literature provides few studies devoted specifically to studies of occupational diseases and occupational illness rate of those employed in wood processing.

Over the last 15 years, a rapid increase of the occupational illness rate has been observed in Latvia; however, the rate has been the lowest in the field of wood, wood, and cork production industry in Latvia, and significantly lower than in the European Union countries. On very rare occasions, acute or sub-acute cases of occupational diseases or chronic occupational diseases in the initial stages have been recorded. The low occupational illness rate amongst those employed in wood processing might be explained by insufficient extensive and systematic studies on the health of this group of persons. Therefore, there is a necessity for a scientifically substantiated study of risk factors of the work environment in the wood processing industry, as well as for evaluation of the health condition of the employed, using modern examination methods. Determination of the relationship between risk factors of the work environment and health indices would allow to prevent difficult, irreversible diseases, which presently have not yet been recognised to be associated with the work environment.

The aims of our study were to determine risk factors of the work environment in the wood processing industry in Latvia during 1998-2006, to conduct a survey and self- evaluation of health of the employees and to elaborate a set of preventive measures for improvement of the work environment.

\section{MATERIALS AND METHODS}

Determination and analysis of risk factors was carried out in wood processing companies by:

- chemical substance sampling and processing (92 samples - formaldehyde, lacquer, etc.);

- wood dust sampling and processing (210 samples - pine, fir tree dust);

- noise measurements at the work locations of workers of the wood processing industry (measurements were made $10-30 \mathrm{~cm}$ from workers'ear according to standard) (195 measurements);

- general and local technology vibration measurements (48 measurements);

- identification of biological agents (five samples).

For analysis, ISO and LVS (Latvian state standard) methods and modern measuring equipment were used (gas chromatograph Varian 3800, Drager analyser for chemical substances, high sensitivity analytical scale "Kern" for gravimetric dust detection, a Controller Integrating Sound Level Meter 2237 for establishing the noise level, 2231 for vibration detection, Testo 400 for assessment of microclimate, and Testo 545 for lighting conditions). In accordance with the technological process, concentration of pollutant chemical substances (formaldehyde, phenol, esters, spirits, hydrocarbon) was determined in the air of the work environment. For detecting concentration of harmful substances in the working environment, sampling was evaluated in the breathing zone of the employee with Buck and GilAir sampling equipment.

An employee survey was conducted in two wood processing companies. The number of the employed in each of the companies was 240-260. The survey was conducted with specially prepared employee questionnaires distributed to 480 persons, of whom 436 submitted completed surveys. The age of the respondents ranged from 18 to $60 ; 25 \%$ were aged $21-30,38 \%-31-40,20 \%-41-50$ years. $87 \%$ were male, $23 \%$ - female respondents.

The survey questionnaire consists of the following parts:

- general information (age, gender, profession, duration of employment, habits);

- questions about the risk factors of the work environment (physical, chemical, psycho-emotional, and ergonomic);

- questions describing the health condition of the employed person (self-assessment, medical opinion);

- work organisation and safety at the work place.

To compare the situation in wood processing with that in other manufacturing industries in Latvia, several surveys were conducted within the framework of the study "Labour conditions and risks in Latvia". The study included the Computer Assisted Telephone Interviews (CATI) using a specialised employer survey questionnaire given to 1,058 respondents. In labour safety specialist surveys (electronically distributed, so-called self-addressed interview questionnaires, to 86 respondents), as well as employee surveys by direct computerised interviews at the residences of the 2,520 respondents (Computer Assisted Personal Interviews (CAPI)), using a specialised on labour conditions and labour environment risks in companies. For some work places, the results of these surveys were used to compare the answers of the respondents to the data of our study, as well as to analyse certain specific questions.

A database (in SPSS software) of risk factors of the working environment was made for seven wood processing companies over a period of ten years. The database includes data on inspections of 940 work places.

The statistical processing of the study results was conducted by SPSS 14.0 software (company SPSS Ltd., USA). In the statistical data analyses, adequate methods were used (Altman, 2003; Teibe, 2007). For data comparison, methods of confidence interval analysis, independent selection t-test and Spearman's rank correlation quotient were used. 


\section{RESULTS}

Establishment of risk factors of the work environment in wood processing companies was implemented in three stages: (1) employer and employee survey; (2) hygienic measurements of risk factors of the working environment; and (3) summary of measurements of the work environment. A targeted survey was conducted with 436 persons employed in wood processing, which included identification of risk factors at the work place, and evaluation of effects on health. The results obtained from the survey show that one of the most important risk factors of the work environment in wood processing is noise, as this was indicated by $91 \%$ respondents. Noise, which was caused by several working processes (sawing, boring, grinding, peeling, shaving), significantly exceeded the regulated permitted noise level of 8 hours $-87 \mathrm{~dB}$. An increased noise level was observed in $73 \%$ of the surveyed working processes. In wood processing, noise originates from the blades of tools of wood processing machines (knife shafts, saws, cutters) when operating in high revolutions per minute.

Besides noise, some wood processing equipment also causes vibration. Local vibration mainly on hands was observed by $26 \%$ respondents, and whole-body vibration by $23 \%$. $9 \%$ of the employed were subjected to both types of vibrations.

Additional health risk for those employed in wood processing can be caused by unsuitable micro-climatic conditions, which are mainly related with temperature and relative humidity, as well as with elevated air movement or draught. Temperature above $21^{\circ} \mathrm{C}$ in combination with low relative humidity causes a sensation of dryness (including dry mucous membranes), eyes, pipes, skin irritation, headache, and drowsiness. This was confirmed by numerous complaints about irritation of pipes, coughing, and headache.

22 per cent of the respondents complained of insufficient lighting, which can cause straining of the optical nerve, faster fatigue, headache, and various eye illnesses. This can decrease the work productivity and can be reason for manufacturing trauma.

Approximately $70 \%$ of the respondents indicate contact with wooden dust. Data on the number of the employees subjected to dust and chemical substances at their work place, and the range of levels of exposure in relation to limiting values of the relevant occupation (LVS 89:2004) displayed in Table 1. Data from 210 measurements of wood dust and 92 measurements of different chemical factors are used.

Wood dust in the air of the working environment in $38 \%$ of cases exceeded the permissible exposition limit (OEL) -6 $\mathrm{mg} / \mathrm{m}^{3}$. The workers are mainly subjected to pine and deciduous tree (birch, oak) dust. High wood dust concentrations were observed in sawing, polishing, shaving, boring, and grinding processes. A low level of dust was observed near wood dryers and around assemblage workers, sorters, gluers, upholsterers, and loaders. The average wood dust concentrations at the work places ranged from 1.0 to 9.6 $\mathrm{mg} / \mathrm{m}^{3}$ (limits of specific measurements $0.5-35.7 \mathrm{mg} / \mathrm{m}^{3}$ ) depending on the working process and ventilation system. The air of the work environment mainly contained ultramicroscopic sized (less than $5 \mu \mathrm{m}$ ) dust, which can deeply

Table 1

NUMBER OF THE EMPLOYED SUBJECTED TO DUST AND CHEMICAL SUBSTANCES AT THEIR WORKPLACE, LEVELS OF EXPOSURE OF DUST AND CHEMICAL SUBSTANCES

\begin{tabular}{|c|c|c|c|}
\hline Chemical risk factor & $\begin{array}{c}\text { Number of employed subject to contact } \\
\text { with harmful factor, } \%\end{array}$ & $\begin{array}{l}\text { Exposure of chemical risk factor, } \\
\qquad \begin{array}{c}\mathrm{mg} / \mathrm{m}^{3} \\
(\mathrm{n}=302)^{*}\end{array}\end{array}$ & $\begin{array}{c}\text { Number of analyses }(\%) \text { exceeding the } \\
\text { limiting values of exposure }\end{array}$ \\
\hline Wood dust & 68.9 & $0.5-35.7$ & $38 \%$ of cases exceed the limits \\
\hline Dissolvent & 16.4 & $11.5-189.9$ & not exceeding \\
\hline Paints & 12.6 & - & - \\
\hline Glue & 10.5 & & \\
\hline - epichlorhydrine, & & $0.01-0.2$ & not exceeding \\
\hline - methylcyclohexane & & $0.5-1.8$ & not exceeding \\
\hline - methylmetacrilate & & $0.02-0.1$ & not exceeding \\
\hline Oil spray & 3.4 & & not exceeding \\
\hline Formaldehyde & 2.9 & $0.15-0.64$ & $22 \%$ of cases exceed the limits \\
\hline Phenol & - & $0.06-0.16$ & not exceeding \\
\hline Lacquers & 2.1 & & \\
\hline - toluene & & $4.2-15.8$ & not exceeding \\
\hline - ethyl acetate & & $20.5-80.2$ & not exceeding \\
\hline Wood impregnation means & 1.7 & & \\
\hline - copper & & $0.02-0.08$ & not exceeding \\
\hline - arsenic & & $0.005-0.015$ & $0.6 \%$ of cases exceed the limits \\
\hline - chrome & & $0.02-0.05$ & $15 \%$ of cases exceed the limits \\
\hline
\end{tabular}

* Exposure level range of chemical risk factors were calculated from 210 wood dust samples and 92 samples of chemical substances 
penetrate the pulmonary organs, where they are deposited, and is the main cause of pneumoconiosis.

Concentrations in air of the chemical substances (formaldehyde, epichlorohydrin, vinylacetate, ethylacetate, methylmetacrilate, methylcyclohexane, stirol, methanol, acetone, toluene, total dissolvents) varied over a wide range, but generally did not exceed the OEL. An exception was formaldehyde, which in $22 \%$ of cases exceeded the OEL. In the air of the work environment, simultaneously several chemical substances can be present and the total concentration in certain cases exceeded the permitted values. Unsuitable conditions were observed in wood processing companies where wood impregnation is performed with preservatives containing toxic chemical substances, such as arsenic, chromium (VI), and copper. For these elements, the concentration in air exceeded the limiting values of occupational exposure by $0.6 \%$ to $15 \%$. Contact with impregnated wooden materials can be dangerous for the employees, as arsenic, chrome and copper were detected in water wash-off from the wooden materials.

Of the 940 measurements performed in the fields of wood processing and furniture manufacturing from 1998 to 2006, noise was the most frequently measured indicator $(21 \%, \mathrm{n}=$ 201), followed by microclimatic indicators including humidity $(15 \%, \mathrm{n}=144)$, temperature $(15 \%, \mathrm{n}=144)$, air flow speed $(16 \%, \mathrm{n}=146))$, manganese $(0.6 \%, \mathrm{n}=62)$, wood dust $(15 \%, \mathrm{n}=139)$, lighting $(10 \%, \mathrm{n}=91)$, vibration of the whole body $(5 \%, \mathrm{n}=42)$. In the work environment of wood processing and furniture manufacturing industries, measurements of welding spray, manganese, and palm-hand vibrations, and asbestos were performed, as they are related to assessment of risk factors present in various spheres of the wood processing industry.
In more than one half of the cases $(51 \%, \mathrm{n}=483)$, the risk factors exceeded the permissible or recommended standards. Noise indicators exceeded the limiting or recommended values of occupational exposure in $72 \%$ of cases $(\mathrm{n}=145)$; of microclimatic factors: humidity in $60 \%$ $(\mathrm{n}=87)$, temperature in $40 \%(\mathrm{n}=57)$, air flow speed in $62 \%(\mathrm{n}=90)$; lighting in $53 \%(\mathrm{n}=48)$, welding spray in $50 \%(n=3)$, vibration of the whole body in $43 \%(n=18)$, wood dust in $23 \%(\mathrm{n}=32)$ of cases, and other risk factors (Table 2).

Elevated exposure was characteristic for noise, air flow speed and humidity, wood dust (exceeded by 1.2 to 2.3 times), as well as welding spray (exceeded by 1.1 to 2.7 times). The average whole body vibration in the working environment in 2002 and 2003 exceeded the permissible exposure. In 2004, the average concentration of asbestos fibres in wood processing and furniture manufacturing industries was within the permissible limits.

\section{DISCUSSION}

The wood processing industry is one of the best developed industrial sectors in Latvia. As it has been shown by our previous studies and those by other authors, from the viewpoint of the occupational health, wood processing is a very difficult industry, because the employees can be simultaneously subjected to extremely varied risk factors of the working environment. The influence of risk factors of the work environment on workers in the wood processing has not been successfully studied worldwide. In the studies performed around the world and in Latvia, the influence on a specific system of the body by specific risk factors is usually studied. Over the last decades, significant modifications in the system of occupational health have transpired in Latvia. Legislation gives higher responsibility to the employers

Table 2

NUMBER OF MEASUREMENTS OF RISK FACTORS NOT COMPLYING WITH THE LIMITING OR RECOMMENDED VALUES OF OCCUPATIONAL EXPOSURE IN THE WORK ENVIRONMENT FROM 1998 TO 2006 IN WOOD PROCESSING AND FURNITURE MANUFACTURING INDUSTRIES (DD20 and DN36) $(\mathrm{n}=940)$ AND NUMBER OF RISK FACTORS IN \%*

\begin{tabular}{|c|c|c|c|c|c|c|}
\hline \multirow{2}{*}{$\begin{array}{c}\text { Indicator assessed at work- } \\
\text { place/process }\end{array}$} & \multicolumn{5}{|c|}{ Year of measurement } & \multirow[t]{2}{*}{ Total } \\
\hline & 2000 & 2002 & 2003 & 2004 & 2005 & \\
\hline Lighting & $1(33 \%)$ & $12(38 \%)$ & $15(58 \%)$ & $16(70 \%)$ & $4(57 \%)$ & $48(53 \%)$ \\
\hline Palm-hand vibration & - & - & $1(33 \%)$ & - & - & $1(8 \%)$ \\
\hline Vibration of whole body & - & $12(50 \%)$ & $6(35 \%)$ & - & - & $18(43 \%)$ \\
\hline Manganese & - & $1(33 \%)$ & $1(50 \%)$ & - & - & $2(33 \%)$ \\
\hline Welding spray & - & $1(33 \%)$ & $1(50 \%)$ & $1(100 \%)$ & - & $3(50 \%)$ \\
\hline Wood dust & $2(10 \%)$ & $15(56 \%)$ & $4(18 \%)$ & $9(31 \%)$ & $2(33 \%)$ & $32(23 \%)$ \\
\hline Relative air humidity & $1(25 \%)$ & $41(76 \%)$ & $14(40 \%)$ & $27(58 \%)$ & $4(100 \%)$ & $87(60 \%)$ \\
\hline Air temperature & $1(25 \%)$ & $23(43 \%)$ & $18(52 \%)$ & $13(28 \%)$ & $2(50 \%)$ & $57(40 \%)$ \\
\hline Air flow movement & $3(43 \%)$ & $34(63 \%)$ & $25(74 \%)$ & $24(51 \%)$ & $4(100 \%)$ & $90(62 \%)$ \\
\hline Noise (Leq**) & $13(81 \%)$ & $42(70 \%)$ & $60(78 \%)$ & $22(65 \%)$ & $8(57 \%)$ & $145(72 \%)$ \\
\hline Total & 21 & 181 & 145 & 112 & 24 & 483 \\
\hline
\end{tabular}

Note: \%*, percentage calculated taking into account the total number of annual measurements of each risk factor and the number of measurements in the relevant year not complying with the normative limits.

** Leq, noise level as calculated for 8 hour work shift. 
regarding labour safety, and health guarantees are currently in development, including also requirements to inform of the risk factors of environmental health and the effects on health. Therefore, complex studies are required in order to evaluate the health condition of those employed in wood processing in relation to all risk factors of the working environment, and to elaborate and recommend the preventive measures for health protection of the employed.

The measurements of risk factors of the work environment in the fields of wood processing and joinery can be used to make an objective evaluation of the current situation in Latvia.

In the field of wood processing and furniture manufacturing, of 940 workplaces/processes, in more than one half of the cases $(n=483)$, the risk factors of the work environment exceeded the permissible or recommended standards. Occupational exposure exceeded the limit values or the recommended values by noise, humidity, temperature, air flow speed, lighting, welding spray, whole body vibration, and wood dust. This indicates that the work conditions in Latvian companies were poor over the research period.

In wood processing, ergonomic risk factors are also typical, for instance, physical overload, moving heavy objects, working in a compulsory position, monotonous work, performing certain work operations, fast paced monotonous repeated movements, etc.

The work conditions in wood processing create a significant problem of occupational health in many countries. For example, in Estonia, wood dust concentration in wood processing companies is similar to that in Latvia (Innos et al., 2000). In the USA, improvement of technological processes over the past 20 years have contributed significantly in decreasing the dust levels in the work environment of wood processing companies and thus are much better than in Latvian companies (Teschke et al., 1994). Furthermore, over the past few decades, concentration of dust, chemical substances, and microorganisms in air of wood processing companies in Denmark has significantly decreased, and during the past decade, is also lower than in Latvian companies (Schlunssen et al., 2001).

Similar studies on the risk factors in wood processing indicate that concentration and levels of wood dust, noise, whole-body vibration, microclimate, welding spray and other chemical substances exceed the permissible limiting values only in a small percentage of cases (Mikkelsen et al., 2002). Thus, there is a need to introduce modern technologies in wood processing companies, as well as implementation of comprehensive and complex preventive measures, which would allow to decrease the risk factors.

Biological risk factors in Latvian wood processing companies have been relatively less studied, but other studies do suggest a possible risk. Extensive studies in this field have been performed in saw mills and furniture manufacturing units in Australia (Alwis et al., 1999) and Poland
(Krysinska-Traczyk et al., 2002). Not only are bacteria and fungi harmful to health, but also the excreted toxins and mycotoxins can produce allergic and other health effects. Our study is the first in Latvia, where the said issues have been considered.

The study showed the importance of chemical pollutants as risk factors in the wood processing companies. The employees working in wood processing are mainly subjected to the effects of organic solvents, glues, lacquers, paints, finishing and cohesive substances. The concentration in air depends on length of the work to be performed, as well as on meteorological conditions and the specifics of the work being done. The components of the products used usually include organic dissoluble substances, which can cause damage to central and peripheral nervous systems (chronic poisoning), allergic illnesses (dermatitis, urticaria), as well as respiratory diseases (bronchial asthma, allergic rhinitis, allergic inflammations of the upper respiratory organs). Duration of influence of the chemical substances and concentration of the substances in the air, as well as the technology used, and machine technical maintenance are of great importance in development of health disturbances (Kal,kis and Roja, 2001).

The conclusions are:

1. The working conditions in wood processing companies in Latvia over the study period were poor, because out of a total of 940 evaluated workplaces/processes, in more than one half of cases $(n=483)$, the risk factors of the work environment exceeded the occupational exposure levels. By analysing the results of measurements made in wood processing and furniture manufacturing, it can be observed that overall, most frequently, limiting values or recommended values of the occupational exposition is exceeded by noise, humidity, temperature, air flow movement, lighting, welding spray, whole-body vibration, wood dust, and other risk factors.

2. Monitoring and control systems for woodworking industry are not properly working and shall be improved as they allow exceeded occupational exposure limits in many workplaces.

3. Self-evaluation of health by employees indicated that the main health problems include pain in the back and joints, poor hearing, eye irritation, skin irritation and inflammation, chronic coughing, rhinitis, recurring windpipe inflammations, and frequent headaches.

4. Self-evaluation of employees indicated the low diagnostics of occupational diseases and work-related diseases; $82 \%$ of the respondents indicated that they had been to mandatory health checks, but in most cases the health complaints have not been confirmed with medical diagnoses.

In order to improve the work conditions, reduce occupational diseases and improve early diagnostics of occupational diseases, the following recommendations were made: 
- ensure proper working environment with special emphasis on dust and other chemical factors (ensure proper ventilation and other preventive measures) as well as on reduction and control of noise and other risk factors;

- when planning and setting up work places, ensure that ergonomic recommendations are followed with special emphasis to height or working area, lifting (distance, type, support available etc.), repetitive movements and awkward postures;

- implement proper systems for monitoring and control of work environment (regular measurements).

\section{REFERENCES}

Alwis, K.U., Mandryk, J., Hocking, A. (1999). Exposure to biohazards in wood dust: Bacteria, fungi, endotoxins and (1-3)- $\beta$-D-glucans. Appl. Occup. Environ. Hyg., 14(9), 598-608.

Altman, D.G. (2003). Practical Statistics for Medical Research. London: Chapman and IHall. 606 pp.

Demers, P.A., Teschke, K., Kennedy, S.M. (1997). What to do about softwood? A review of respiratory effects and recommendations regarding exposure limits. Amer. J. Ind. Med., 4, 358-359.

Donham, K., Thorne, P. (1994). Agents in organic dust: Criteria for a causal relationship. Amer. J. Ind. Med., 25, 33-39.

Douves, J., McLean, D., van der Maarl, E. (2000). Worker exposures to airborne dust, endotoxin and $\beta(1,3)$ - glucan in two New Zealand sawmills. Amer. J. Ind. Med., 38, 426-430.

Dutkiewicz, J., Skorska, C., Krysinska-Traczyk, E., Dutkiewick, E., Matuszyk, A., Sitkowska, J. (2001). Response of sawmill workers to work-related allergens. Ann. Agric. Environ. Med., 8, 81-90.

Innos, K., Rahu, M., Rahu, K., Lang, I., Leon, D. (2000). Wood dust exposure and cancer incidence: Retrospective cohort study of furniture workers industry in Estonia. Amer. J. Ind. Med., 37, 501-511.
Kaḷkis,V., Roja, Ž. (red.). (2001). Darba vides riska faktori un strādājošo veselības aizsardzība [Occupational Risk Factors and Health Protection of Workers]. Elpa, Rīga. 500. 1pp. (in Latvian).

Kauppinen, T.P., Teschke, K., Savela, A., Kogevinas, M., Boffetta, P. (1997) International data base of exposure measurements in the pulp, paper and paper product industries. Int. Arch. Occup. Environ. Health, 70, 119-127.

Kauppinen, T., Vincent, R., Liukkonen, T. (2006). Occupational exposure to inhalable wood dust in the member states of the European Union. Ann. Occup. Hyg., 50, 549-561.

Kraus, T., Pfahlberg, A., Zobelen, P., Gefeller, O., Raithel, H.J. (2004). Lung function among workers in the soft tissue paper-producing industry. Chest, 125, 731-736.

Krysinska-Traczyk, E., Skorska, C., Choleva, G., Sitkovska, J., Milanovski, J., Dutkiewicz, J. (2002). Exposure to airborne microorganisms in furniture factories. Ann. Agric. Environ. Med., 9, 85-90.

Mandryk, J., Alwais, K.U., Hocking, A.D. (2000). Effects of personal exposures on pulmonary function and work-related symptoms among sawmill workers. Ann. Occup. Hyg., 44, 281-289.

Mikkelson, A., Schlunssen, V., Sigsgaard, T. (2002). Determinants of wood dust exposure in the Danish furniture industry. Ann. Ocup. Hyg., 46, 673-685.

Priha, E., Pennanen, S., Ratio, T. (2004). Exposure to and acute effects of medium-density fiber board dust. J. Occup Environ Hyg., 1(11), 738-744.

Schlunssen, V., Vinzents, P., Mikkelsen, A.B., Schaumburg, I. (2001). Wood dust exposure in the Danish furniture industry using conventional and passive monitors. Ann. Occup. Hyg., 45(2), 157-164.

Staša, J., Roja, Ž. (2001). Kokapstrāde [Wood processing industry]. Grām.: Darba vides riska faktori un strādājošo veselības aizsardzība. Rīga: Elpa, 359.-370. 1pp. (in Latvian).

Teibe, U. (2007). Biologiskāa statistika [Biological Statistics]. Rīga: LU akadēmiskais apgāds. 155 lpp. (in Latvian).

Teschke, K., Hertzman, C. Morrison, B. (1994). Level and distribution of exposures to total and respirable wood dust in two Canadian sawmills. Amer. Ind. Hyg. Assoc. J., 55, 245-250.

Received 18 March 2010

\section{DARBA VIDES RISKA FAKTORU UN STRĀDĀJOŠO VESELĪBAS STĀVOKLA PAŠNOVĒRTĒJUMS KOKAPSTRĀDĒ}

Darbā veikta galveno darba vides riska faktoru novērtēšana Latvijas kokapstrādes uzṇēmumos laika periodā no 1998 . gada līdz 2006. gadam, kā arī analizēts strādājošo veselības stāvokḷa pašnovērtējums. Darba apstākḷi Latvijas kokapstrādes uzṇēmumos pētāmajā laika posmā bijuši slikti, jo kopumā no 940 novērtētām darba vietām/procesiem vairāk kā pusē gadījumu darba vides riska faktori pārsniedz piẹ̦aujamās vai rekomendējamās normas. Kopumā visvairāk aroda ekspozīcijas robežvērtības vai rekomendējamos lielumus pārsniedz troksnis, mikroklimata rādītāji, temperatūra, apgaismojums, vibrācija, koksnes putekḷi u.c. riska faktori. Kā svarīgākās sūdzības, pēc pašu nodarbināto vērtējuma, ir sāpes mugurā un locìtavās, pavājināta dzirde, acu kairinājums, ādas nieze un iekaisums, hronisks klepus, iesnas, atkārtoti elpceḷu iekaisumi, biežas galvassāpes. Darbinieku veselības stāvokḷa pašnovērtējums norādīja uz nepietiekamu arodslimību un ar darbu saistīto slimību diagnostiku, jo $82 \%$ nodarbināto ar sūdzībām par veselības stāvokli, tās netika apstiprinātas ar diagnozi. 